\title{
IAMJ
}

INTERNATIONAL

AYURVEDIC

MEDICAL JOURNAL

Impact Factor: 6.719

Research Article

ISSN: 2320-5091

\section{A CLINICAL STUDY ON EFFECTIVENESS OF ASHWAGANDHA (WITANIA SOMNIFERA) ON QUALITY OF LIFE (WHOQOL-BREF) IN APPARENTLY HEALTHY SUBJCETS}

\author{
Bargale Sushant Sukumar ${ }^{1}$, T. B. Tripathy ${ }^{2}$, Shashirekha H. K. ${ }^{3}$ \\ ${ }^{1} \mathrm{Ph}$. D scholar and Assistant Professor, ${ }^{2}$ Professor, \\ Department of Swasthavritta, Sri Dharmasthala Manjunatheshwara College of Ayurveda and Hospital, \\ Hassan- 573201, Karnataka, India \\ ${ }^{3}$ Associate Professor, Department of Samhita Sanskrit, Faculty of Ayurveda, Institute of medical science, Banaras \\ Hindu university, Varanasi, U.P., India
}

Corresponding Author: dr.sushant99@gmail.com

\section{https://doi.org/ $10.46607 /$ iamj 1008122020}

(Published online: December 2020)

Open Access

(C) International Ayurvedic Medical Journal, India 2020

Article Received: 27/11/2020 - Peer Reviewed: 28/11/2020 - Accepted for Publication: 30/11/2020

Check for updates

\section{ABSTRACT}

WHOQOL- BREF is assessment of a multidimensional concept incorporating an individual's perception of health status embedded with physical, psychological, social, and environmental domains. Various types of health issues are common around the globe due to improper sleep pattern and lifestyle. Ashwagandha (Withania Somnifera) is the intervention of many clinical conditions like, arresting the aging process, procure the body in debilitating condition by creating a sense of mental wellbeing and increase physical fitness. Ashwagandha possesses Vatakaphahara, Jara Vyadhi Nashaka, Balya and Dhatu Vriddhikara properties. Because of these properties, it acts not only preventive but also promotive and curative effects as well as slowdown Jara by breaking the pathogenesis. The present study was opted to analyse the health status (quality of life WHO-QOL BREF)in apparently healthy voluntary subjects. Objective: To evaluate the effectiveness of Ashwagandha (Withania Somnifera) on quality of life (WHOQOL-BREF) in apparently healthy subjects. Methods: The study includes randomized, single blind controlled comparative study with pre-test and post-test design. 408 apparently healthy subjects were screened for the features of health. 108 apparently Healthy subjects were selected by considering the inclusion criteria, and categorised into two group, (Group 1- control Group and Group 2- study Group) 54 subjects in each group. Subjects in the study group consumed $12 \mathrm{gm}$ of Ashwagandha Choorna (powder) once daily with milk 200ml and the control 
group consumed milk $200 \mathrm{ml}$ daily once. WHO-QOL BREF Questionnaire was utilised for analysing the health status of the individuals before intervention, after intervention and follow up. Results: In the control group $(n=54)$, the mean score overall quality of life was found to be 65.75 before intervention, after complete intervention quality of life was found to be 67.55 and at the time of follow up quality of life was found 67.55. In the study group ( $n=54)$, the mean score overall quality of life was found to be 64.38 before intervention of study, after complete intervention quality of life was found to be 71.58 and at the time of follow up quality of life was found 71.61. Conclusion: In this study, subjects were improved to the higher scores among the physical, psychological domains as comparison with the environmental and social domains. Found improvement in the quality of life (WHO BREF) in study group as compared to control group.

Keywords: Quality of life, Health status, Ashwagandha, Withania Somnifera, WHOQOL BREF.

\section{INTRODUCTION}

Balanced or normal state of Dhatu which produces Sukha is Prakruti is Arogya (Health) whereas Abnormal state of Dhatu produces Dukha is termed as Vikara (disease). ${ }^{1}$ The person without or minimal abnormality or any disease is known as Swastha (healthy). ${ }^{2}$ The features of a Swastha Purusha (healthy man) are Doshas (Vata, Pitta, Kapha), Agni (digestive fire), Dhatu, Mala (waste products) and Kriya are normal, Atma (soul), Indriya (sense organ) and Manas (mind) are peaceful is said to be Swastha (healthy). Swastha (health) implies the equilibrium state in bodily elements, digestive power, Dhatu, Mala along with mental, sensory and spiritual pleasantness and happiness. ${ }^{3}$ According to world health organization (WHO) health is a state of complete physical, mental and social wellbeing and not merely the absence of disease or infirmity. Health promotion is the process of enabling people to increase control over their health and its determinants, and thereby improve their health. Physical activity provides important health benefits and can enhance the quality of life in adults. Good health is a major resource for social, economic and personal development and an important dimension of quality of life. $^{4}$

Ashwagandha (W. Somnifera) has the property of Rasayana as mentioned in literature. It not only maintains the equilibrium of Dosha and Dhatu of the body but also promotes the health. Ashwagandha is $\mathrm{Va}$ takaphahara, Jara Vyadhi Nashaka, Balya and Dhatu Vriddhikara properties. Because of these properties, it shows not only preventive but also promotive and curative effects as well as slowdown Jara by breaking the pathogenesis. Ashwagandha improves the quality of life, maintains the positive health, preserves youthness and cures morbid sleep, drowsiness, physical as well as mental fatigue, laziness and weakness. It maintains proper balance of the Tridosha, stability, cures slothness of the muscles, stimulates the Agni (digestion and metabolism), excellence in lustre, complexion as well as voice. ${ }^{5,6,7}$ Physical dimensions are "good complexion, clean skin, bright eyes, lustrous hair with body well clothed with firm flesh, not to fat, sweet breath, good appetite, sound sleep, coordinated bodily movements. All the organs of the body are of unexceptional size and function normalcy; all the special senses are intact the resting pulse rate, blood pressure and exercise tolerance are all within the range of normality for the individuals age and gender". ${ }^{8}$ The properties of Ashwagandha are Tikta, Katu, Madhura Rasa, Ushna Veerya, Madhura Vipa$k a$, Kaphavatahara, Rasayana, Vedanasthapana, Deepana, Anuloma, Rkatashodhaka, Vrishya, Dhatu Vruddhikara, Bala Pushtiprada. ${ }^{910}$ Withania Somnifera is an Immuno-modulatory, anti-inflammatory and anti-oxidizing agent. Ashwagandha has been used as a Rasayana. The root of Ashwagandha is regarded as tonic, aphrodisiac, narcotic, diuretic, anthelmintic, and astringent, thermo genic and stimulant. It is commonly used in emaciation of children (when given with milk, it is the best tonic for children), debility from old age, rheumatism, vitiated conditions of Vata, leu- 
coderma, constipation, insomnia, nervous breakdown, goitre etc. ${ }^{11}$

Objective: To evaluate the effectiveness of Ashwagandha (Withania Somnifera) on quality of life (WHOQOL-BREF) in apparently healthy subjects.

\section{Materials and methods}

This randomized, single blind controlled comparative study with pre-test and post-test design was approved by Institutional Ethics committee Sri Dharmasthala Manjunatheshwara college of Ayurveda and hospital, Hassan, Karnataka India (IEC No: SDM/IEC/92/2016-2017 dt.25 June 2016) and study was conducted in compliance with good clinical practice guidelines, declaration of Helsinki and all other applicable regulations. CTRI no- 2019/05/019009.

Source of data: Apparently healthy subjects from OPD of SDM college of Ayurveda and Hospital, Hassan either gender who are fulfilling the criteria of inclusion are selected irrespective of gender and caste etc.

Method of collection of data (including sampling procedure, if any) Survey- 408 apparently healthy subjects was screened for the features of Arogya (health). 108 apparently healthy subjects were selected by considering the inclusion criteria.

\section{Criteria for selection of subjects:}

Inclusion criteria- Apparently Healthy subjects who were interested and willing to take Ashwagandha (Withania Somnifera) and subjects of age group 18-40 yrs.

Exclusion criteria- Pregnant women, lactating women etc.

Duration of the study: 60 days for both study and control groups.
Follow up: After 1 month of completion on intervention.

Grouping: Two groups of 54 persons each was taken. Intervention: The included subjects were randomly divided under two groups, Group 1(control group) and Group 2 (study group).

Group 1- In 54 subjects administered 2 Haritaki tablets for Kostha Shuddhi with hot water for minimum of 3 days and $200 \mathrm{ml} \mathrm{Dugdha} \mathrm{(milk)} \mathrm{for} 60$ days in empty stomach early in the morning kept as a control.

Group 2- In 54 subjects administered 2 Haritaki tablets for Kostha Shuddhi with hot water for minimum of 3 days and 12gm of Ashwagandha Choorna with $200 \mathrm{ml}$ Dugdha (milk) for 60 days in empty stomach early in the morning.

Medicine Name: Ashwagandha Choorna

Study Design: 108 apparently healthy subjects were selected for clinical study. WHO-QOL BREF health assessment Questionnaire on health status was used for analysing the health status of individuals (as per inclusion and exclusion criteria).

Assessment Criteria: Health status was analyzed from the score obtained by the questionnaire.

Subjective Parameters: Health assessment questionnaire - WHO-QOL BREF

\section{Statistical Analysis:}

Software 'Statistical Package for Social Sciences', Version 20 was used for the statistical analysis. Data were analysed by using WHO QOL tool, percentage, and proportions.

\section{Scoring pattern of the questionnaire}

1) WHO QOL BREF ${ }^{12}$

a) Following questions from 1-2 and 5-25 belonging to various domains of WHO-QOL was positively graded as shown in the table.

Table 1: WHO-QOL Positive Scale Grading

\begin{tabular}{|l|l|}
\hline Not at all & 1 \\
\hline A little & 2 \\
\hline A moderate amount & 3 \\
\hline Very much & 4 \\
\hline An extreme amount & 5 \\
\hline
\end{tabular}

b) Questions 3, 4 and 26 were graded negatively as shown in the table 
Table 2: WHO-QOL Negative Scale Grading

\begin{tabular}{|l|l|}
\hline Not at all & 5 \\
\hline A little & 4 \\
\hline Very much & 3 \\
\hline An extreme amount & 2 \\
\hline
\end{tabular}

Following are 26 questions containing 4 domains like, physical, psychological, socio-economic and environmental.

The question 1 and 2 are two subjective questions with positive scale grading

1. How would you rate your quality of life?

2. How satisfied are you with your health?

The remaining 24 questions are taken for the calculation

1. To what extent do you feel that (physical) pain prevents you from doing what you need to do?

2. How much do you need any medical intervention to function in your daily life?

3. How much do you enjoy life?

4. To what extent do you feel your life to be meaningful?

5. How well are you able to concentrate?

6. How safe do you feel in your daily life?

7. How healthy is your physical environment?

8. Do you have enough energy for everyday life?

9. Are you able to accept your bodily appearance?

10. Have you enough money to meet your needs?

11. How available to you is the information that you need in your day-to-day life?

12. To what extent do you have the opportunity for leisure activities?

13. How well are you able to get around?

14. How satisfied are you with your sleep?

15. How satisfied are you with your ability to perform your daily living activities?

16. How satisfied are you with your capacity for work?

17. How satisfied are you with yourself?

18. How satisfied are you with your personal relationships?

19. How satisfied are you with your sex life?
20. How satisfied are you with the support you get from your friends?

21. How satisfied are you with the conditions of your living place?

22. How satisfied are you with your access to health services?

23. How satisfied are you with your transport?

24. How often do you have negative feelings such as blue mood, despair, anxiety, depression?

\section{Statistical Calculation:}

The WHOQOL-BREF (WHO Quality of Life-Bref) produces four domain scores. There are also two items that were examined separately: question number one is about an individual overall perception of quality of life and question number two is about an individual overall perception of health. Domain scores were scaled in a positive direction (i.e. higher scores denote higher quality of life). The mean score of items within each domain is used to calculate the domain score. Mean scores are then multiplied by 4 in order to make domain scores comparable with the scores used in the WHOQOL-100, and subsequently transformed to a 0 100 scale, using the formula below.

A method for the manual calculation of individual scores is below:

Physical domain $=((6-\mathrm{Q} 3)+(6-\mathrm{Q} 4)+\mathrm{Q} 10+\mathrm{Q} 15+$ Q16+Q17+Q18) x4.

Psychological domain $=(\mathrm{Q} 5+\mathrm{Q} 6+\mathrm{Q} 7+\mathrm{Q} 11+\mathrm{Q} 19$ $+(6-\mathrm{Q} 26)) \mathrm{x} 4$.

Social Relationships domain $=(\mathrm{Q} 20+\mathrm{Q} 21+\mathrm{Q} 22) \times 4$. Environment domain $=(\mathrm{Q} 8+\mathrm{Q} 9+\mathrm{Q} 12+\mathrm{Q} 13+\mathrm{Q} 14+$ Q23+Q24 +Q25) x4.

Response scales: For this WHOQOL, there are 4-5point response scales concerned with the intensity $\mathrm{Ca}-$ pacity, frequency and evaluation of states or behaviour. So, these facts were also assessed. 
Table 3: Method for converting raw scores to transformed scores

\begin{tabular}{|c|c|c|c|c|c|c|c|c|c|c|c|}
\hline \multicolumn{3}{|c|}{ DOMAIN 1} & \multicolumn{3}{|c|}{ DOMAIN 2} & \multicolumn{3}{|c|}{ DOMAIN 3} & \multicolumn{3}{|c|}{ DOMAIN 4} \\
\hline \multirow[t]{2}{*}{$\begin{array}{l}\text { Raw } \\
\text { Score }\end{array}$} & \multicolumn{2}{|c|}{$\begin{array}{l}\text { Transformed } \\
\text { scores }\end{array}$} & \multirow[t]{2}{*}{$\begin{array}{l}\text { Raw } \\
\text { Score }\end{array}$} & \multicolumn{2}{|c|}{$\begin{array}{l}\text { Transformed } \\
\text { scores }\end{array}$} & \multirow[t]{2}{*}{$\begin{array}{l}\text { Raw } \\
\text { Score }\end{array}$} & \multicolumn{2}{|c|}{$\begin{array}{l}\text { Transformed } \\
\text { scores }\end{array}$} & \multirow[t]{2}{*}{$\begin{array}{l}\text { Raw } \\
\text { Score }\end{array}$} & \multicolumn{2}{|c|}{ Transformed scores } \\
\hline & $4-20$ & $0-100$ & & $4-20$ & $0-100$ & & $4-20$ & $0-100$ & & $4-20$ & $0-100$ \\
\hline 7 & 4 & 0 & 6 & 4 & 0 & 3 & 4 & 0 & 8 & 4 & 0 \\
\hline 8 & 5 & 6 & 7 & 5 & 6 & 4 & 5 & 6 & 9 & 5 & 6 \\
\hline 9 & 5 & 6 & 8 & 5 & 6 & 5 & 7 & 19 & 10 & 5 & 6 \\
\hline 10 & 6 & 13 & 9 & 6 & 13 & 6 & 8 & 25 & 11 & 6 & 13 \\
\hline 11 & 6 & 13 & 10 & 7 & 19 & 7 & 9 & 31 & 12 & 6 & 13 \\
\hline 12 & 7 & 19 & 11 & 7 & 19 & 8 & 11 & 44 & 13 & 7 & 19 \\
\hline 13 & 7 & 19 & 12 & 8 & 25 & 9 & 12 & 50 & 14 & 7 & 19 \\
\hline 14 & 8 & 25 & 13 & 9 & 31 & 10 & 13 & 56 & 15 & 8 & 25 \\
\hline 15 & 9 & 31 & 14 & 9 & 31 & 11 & 15 & 69 & 16 & 8 & 25 \\
\hline 16 & 9 & 31 & 15 & 10 & 38 & 12 & 16 & 75 & 17 & 9 & 31 \\
\hline 17 & 10 & 38 & 16 & 11 & 44 & 13 & 17 & 81 & 18 & 9 & 31 \\
\hline 18 & 10 & 38 & 17 & 11 & 44 & 14 & 19 & 94 & 19 & 10 & 38 \\
\hline 19 & 11 & 44 & 18 & 12 & 50 & 15 & 20 & 100 & 20 & 10 & 38 \\
\hline 20 & 11 & 44 & 19 & 13 & 56 & & & & 21 & 11 & 44 \\
\hline 21 & 12 & 50 & 20 & 13 & 56 & & & & 22 & 11 & 44 \\
\hline 22 & 13 & 56 & 21 & 14 & 63 & & & & 23 & 12 & 50 \\
\hline 23 & 13 & 56 & 22 & 15 & 69 & & & & 24 & 12 & 50 \\
\hline 24 & 14 & 63 & 23 & 15 & 69 & & & & 25 & 13 & 56 \\
\hline 25 & 14 & 63 & 24 & 16 & 75 & & & & 26 & 13 & 56 \\
\hline 26 & 15 & 69 & 25 & 17 & 81 & & & & 27 & 14 & 63 \\
\hline 27 & 15 & 69 & 26 & 17 & 81 & & & & 28 & 14 & 63 \\
\hline 28 & 16 & 75 & 27 & 18 & 88 & & & & 29 & 15 & 69 \\
\hline 29 & 17 & 81 & 28 & 19 & 94 & & & & 30 & 15 & 69 \\
\hline 30 & 17 & 81 & 29 & 19 & 94 & & & & 31 & 16 & 75 \\
\hline 31 & 18 & 88 & 30 & 20 & 100 & & & & 32 & 16 & 75 \\
\hline 32 & 18 & 88 & & & & & & & 33 & 17 & 81 \\
\hline 33 & 19 & 94 & & & & & & & 32 & 17 & 81 \\
\hline 34 & 19 & 94 & & & & & & & 35 & 18 & 88 \\
\hline 35 & 20 & 100 & & & & & & & 36 & 18 & 88 \\
\hline & & & & & & & & & 37 & 19 & 94 \\
\hline & & & & & & & & & 38 & 19 & 94 \\
\hline & & & & & & & & & 39 & 20 & 100 \\
\hline & & & & & & & & & 40 & 20 & 100 \\
\hline
\end{tabular}

Table 4: Assessment Table

\begin{tabular}{|l|l|l|l|}
\hline Health Status & Score & Percentage & Total \\
\hline Domain 1 & & & \\
\hline Domain 2 & & & \\
\hline Domain 3 & & & \\
\hline Domain 4 & & \\
\hline
\end{tabular}


Table 5: Screening / enrolment- Total 408 screened subjects and 114 subjects included in study.

\section{Patient Enrolment}

Screening for eligibility $=$ Total 408 Subjects

Total subjects selected $=114$ subjects

Randomized ( $\mathrm{n}=114)$

Allocated in Group 1( $\mathrm{n}=57)$

Baseline evaluation $(n=57)$

Evaluation after intervention 60 days $(\mathrm{n}=54)$

Dropout (3 subjects)

Follow up 90 day $(\mathrm{n}=54)$

Efficacy analysis $(n=54)$

\section{Observational \& Results}

Among 408 screened subjects and 114 subjects were included in study. Though the majority of 246

Table 6: Gender Distribution of the Subjects in screening

\begin{tabular}{|l|l|l|}
\hline Gender & Frequency & Percentage \\
\hline Male & 246 & 60.30 \\
\hline Female & 162 & 39.70 \\
\hline Total & 408 & 100 \\
\hline
\end{tabular}

Among 114 subjects included in study 114 (100\%) were males. (Table No.07)

Table 7: Gender Distribution of the Subjects in included in study

\begin{tabular}{|l|l|l|}
\hline Gender & Frequency & Percentage \\
\hline Male & 114 & 100 \\
\hline Total & 114 & 100 \\
\hline
\end{tabular}

The age group of subjects showed that among 114, the majority of $112(98.22 \%)$ subjects belonged to the age group of 18 to 25 completed years followed by 02 (1.75\%) subjects belonged to 26-35 years. (Table No. 8).

Table 8: Age Distribution of the Subjects

\begin{tabular}{|l|l|l|}
\hline Age (in completed years) & Frequency & Percent \\
\hline $18-25$ & 112 & 98.22 \\
\hline $26-35$ & 02 & 1.75 \\
\hline $36-45$ & 00 & 00 \\
\hline Total & 114 & 100 \\
\hline
\end{tabular}

Among 114 subjects, majority of $102(89.45 \%)$ had completed the schooling till PUC and $12(10.52 \%)$ subjects were graduates. (Table No. 09)

Table 9: Educational Status of Subjects

Educational qualification

Below Graduation (PUC)

Frequency

Percent

Graduate

102

89.45

Postgraduate

12

00

10.52

Total

114
Allocated in Group $2(\mathrm{n}=57)$

Baseline evaluation $(\mathrm{n}=57)$

Evaluation after intervention 60 days $(\mathrm{n}=54)$

(39.70\%) subjects were females. (Table No.06) 
Among 114 subjects, majority of 84 (73.67\%) subjects having joint family and $30(26.33 \%)$ subjects having nuclear family. (Table No. 10)

Table 10: Type of family

Type of family

Joint

Nuclear

Total

\begin{tabular}{|l|l|}
\hline Frequency & Percent \\
\hline 84 & 73.67 \\
\hline 30 & 26.33 \\
\hline 114 & 100 \\
\hline
\end{tabular}

jects having good housing condition and $02(1.75 \%)$ having very good housing condition. (Table No. 11)

Among 114 subjects, majority of 70 (61.39\%) subjects

having poor housing condition, $32(28.09 \%)$ subjects

having moderate housing condition, $10(8.77 \%)$ sub-

Table 11: Housing condition-

\begin{tabular}{|l|l|l|}
\hline Housing condition & Frequency & Percent \\
\hline Poor & 70 & 61.39 \\
\hline Moderate & 32 & 28.09 \\
\hline Good & 10 & 08.77 \\
\hline Very good & 02 & 01.75 \\
\hline Total & 114 & 100 \\
\hline
\end{tabular}

Among 114 subjects, all the subject having mixed food (vegetarian and non-vegetarian) (Table No. 12)

Table 12: Food Habits (Vegetarian or Mixed)

Food (vegetarian and non-vegetarian)

Vegetarian

Mixed

Total

\begin{tabular}{|l|l|}
\hline Frequency & Percent \\
\hline 00 & 00 \\
\hline 114 & 100 \\
\hline 114 & 100 \\
\hline
\end{tabular}

Among 114 subjects, majority $86(75.44 \%)$ consume the food timely and 28 (24.56) consume untimely. (Table no.13)

Table 13: Food consumption (Timely consumption / Untimely consumption / frequent food intake)

\begin{tabular}{|l|l|l|}
\hline $\begin{array}{l}\text { Food consumption (Timely consumption / Untimely consump- } \\
\text { tion / frequent food intake) }\end{array}$ & Frequency & Percent \\
\hline Timely consumption & 86 & 75.44 \\
\hline Untimely consumption & 28 & 24.56 \\
\hline Frequent food intake & 00 & 00 \\
\hline Total & 114 & 100
\end{tabular}

Among 114 subjects, majority $78(68.40 \%)$ were of Vata Pitta Kapha Prakruti. A total of 15(13.15\%) belonged to Pitta Vata Kapha Prakruti, o2 (1.75\%) each of Pitta Vata Kapha, Pitta Kapha Vata, Vata Pitta Kapha and 15(13.15\%) were belonged to Vata Kapha Pitta Prakruti (Table no. 14).

Table 14: Prakruti Distribution of the Subjects

\begin{tabular}{|l|l|l|}
\hline Prakruti & Frequency & Percent \\
\hline VPK & 78 & 68.40 \\
\hline PVK & 15 & 13.15 \\
\hline PVK & 2 & 1.75 \\
\hline
\end{tabular}




\begin{tabular}{|l|l|l|}
\hline PKV & 2 & 1.75 \\
\hline VPK & 2 & 1.75 \\
\hline VKP & 15 & 13.15 \\
\hline Total & 114 & 100 \\
\hline
\end{tabular}

The two subjective questions of WHO QOL

1. Rating the quality of life-

Group 1 (Control Group)-Among the 54 subjects maximum of $54(100 \%)$ were good with their quality of life before intervention. After intervention 52
(96.2\%) subjects were good with their quality of life and $2(3.8 \%)$ were very good with their quality of life. At follow up $52(96.2 \%)$ subjects were good with their quality of life and $2(3.8 \%)$ were very good with their quality of life. (Table no. 15).

Table 15: Rating the quality of life ( $\mathrm{n}=54)$ Group A

\begin{tabular}{|l|l|l|l|l|l|l|}
\hline Option & $\begin{array}{l}\text { Frequency Before } \\
\text { Intervention }\end{array}$ & Percentage & $\begin{array}{l}\text { Frequency After } \\
\text { Intervention }\end{array}$ & Percentage & $\begin{array}{l}\text { Frequency At } \\
\text { Follow Up }\end{array}$ & Percentage \\
\hline Very Poor & 00 & 00 & 00 & 00 & 00 & 00 \\
\hline Poor & 00 & 00 & 00 & 00 & 00 & 00 \\
\hline Neither Poor Nor Good & 00 & 00 & 00 & 00 & 00 & 00 \\
\hline Good & 54 & 100 & 52 & 96.2 & 52 & 96.2 \\
\hline Very Good & 00 & 00 & 02 & 3.8 & 02 & 3.8 \\
\hline
\end{tabular}

Group 2 (study Group)-Among the 54 subjects maximum of $52(100 \%)$ were good with their quality of life before intervention. After intervention 52 (96.2\%) subjects were very good with their quality of life and
$2(3.8 \%)$ were good with their quality of life. At follow up $52(96.2 \%)$ subjects were very good with their quality of life and $2(3.8 \%)$ were good with their quality of life. (Table no. 16).

Table 16: Rating the quality of life ( $\mathrm{n}=54)$ Group B

\begin{tabular}{|c|c|c|c|c|c|c|}
\hline Option & $\begin{array}{ll}\text { Frequency } & \text { Before } \\
\text { intervention } & \end{array}$ & Percentage & $\begin{array}{l}\text { Frequency after } \\
\text { intervention }\end{array}$ & Percentage & $\begin{array}{l}\text { Frequency at } \\
\text { follow up }\end{array}$ & Percentage \\
\hline Very poor & 00 & 00 & 00 & 00 & 00 & 00 \\
\hline Poor & 00 & 00 & 00 & 00 & 00 & 00 \\
\hline $\begin{array}{l}\text { Neither poor } \\
\text { nor good }\end{array}$ & 02 & 3.8 & 00 & 00 & 00 & 00 \\
\hline Good & 52 & 96.2 & 02 & 3.8 & 02 & 3.8 \\
\hline Very good & 02 & 3.8 & 52 & 96.2 & 52 & 96.2 \\
\hline
\end{tabular}

\section{Health satisfaction-}

Group 1 (Control Group)-Among the 54 subjects maximum of $54(100 \%)$ were satisfied with their health satisfaction before intervention. After intervention $52(96.2 \%)$ subjects weresatisfied with their health satisfaction and $2(3.8 \%)$ were very satisfied with their health satisfaction. At follow up 52 (96.2\%) subjects were satisfied with their health satisfaction and $2(3.8 \%)$ were very satisfied with their health satisfaction. (Table no. 17). 
Table 17: Health satisfaction ( $\mathrm{n}=54)$ Group A

\begin{tabular}{|l|l|l|l|l|l|l|}
\hline Option & $\begin{array}{l}\text { Frequency Before } \\
\text { intervention }\end{array}$ & Percentage & $\begin{array}{l}\text { Frequency after in- } \\
\text { tervention }\end{array}$ & Percentage & $\begin{array}{l}\text { Frequency at } \\
\text { follow up }\end{array}$ & Percentage \\
\hline Very dissatisfied & 00 & 00 & 00 & 00 & 00 & 00 \\
\hline Dissatisfied & 00 & 00 & 00 & 00 & 00 & 00 \\
\hline Moderate & 00 & 00 & 00 & 00 & 00 & 00 \\
\hline Satisfied & 54 & 100 & 52 & 96.2 & 52 & 96.2 \\
\hline Very satisfied & 00 & 00 & 02 & 3.8 & 02 & 3.8 \\
\hline
\end{tabular}

Group 2 (study Group)-Among the 54 subjects maximum of $53(100 \%)$ were satisfied and $1(1.85 \%)$ were very satisfied with their health satisfaction before intervention. After intervention $38(70.33 \%)$ subjects were satisfied with their health satisfaction and 16
(29.61\%) were very satisfied with their health satisfaction. At follow up $38(70.33 \%)$ subjects were satisfied with their health satisfaction and 16 (29.61\%) were very satisfied with their health satisfaction. (Table no. 18).

Table 18: Health satisfaction ( $\mathrm{n}=54)$ Group B

\begin{tabular}{|c|c|c|c|c|c|c|}
\hline Option & $\begin{array}{l}\text { Frequency } \\
\text { intervention }\end{array}$ & Percentage & $\begin{array}{l}\text { Frequency after in- } \\
\text { tervention }\end{array}$ & Percentage & $\begin{array}{l}\text { Frequency at } \\
\text { follow up }\end{array}$ & Percentage \\
\hline $\begin{array}{l}\text { Very dissatis- } \\
\text { fied }\end{array}$ & 00 & 00 & 00 & 00 & 00 & 00 \\
\hline Dissatisfied & 00 & 00 & 00 & 00 & 00 & 00 \\
\hline Moderate & 00 & 00 & 00 & 00 & 00 & 00 \\
\hline Satisfied & 53 & 98.10 & 38 & 70.33 & 38 & 70.33 \\
\hline Very satisfied & 01 & 1.85 & 16 & 29.61 & 16 & 29.61 \\
\hline
\end{tabular}

Total WHO QOL health statusGroup 1 (Control Group)-

Among the 54 subjects, Physical health status (Domain 1) was $81 \%$ before intervention, $88.22 \%$ after intervention and $88 \%$ follow up.

Among the 54 subjects, Psychological health status (Domain 2) was 69\% before intervention, $69.22 \%$ after intervention and $69.22 \%$ follow up.
Among the 54 subjects, Social Relations status (Domain 3) was $44 \%$ before intervention, $44 \%$ after intervention and $44 \%$ follow up.

Among the 54 subjects, Environment factors status (Domain 4) was 69\% before intervention, 69.22\% after intervention and $69 \%$ follow up. (Table no. 19).

Table 19: Assessment of quality of life in Group 1 (Control Group)

\begin{tabular}{|l|l|l|l|l|}
\hline & N & Before Intervention & After Intervention & Follow up \\
\hline Physical health (Domian-1) & 54 & 81 & 88.22 & 88 \\
\hline Psychological health (Domian-2) & 54 & 69 & 69.22 & 69.22 \\
\hline Social Relations (Domian-3) & 54 & 44 & 44 & 44 \\
\hline Environment factors (Domian-4) & 54 & 69 & 69.22 & 69 \\
\hline Overall & 54 & 65.75 & 67.65 & 67.55 \\
\hline
\end{tabular}


Figure 1: Assessment of quality of life in Group 1 (Control Group)

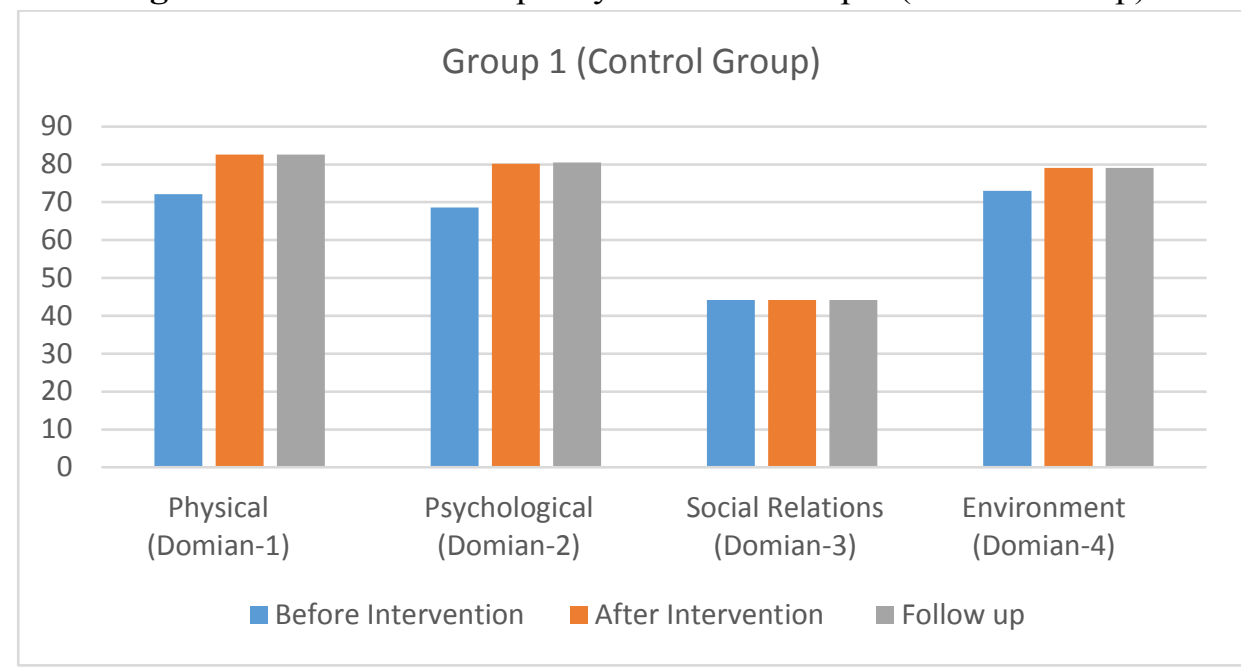

Group 2 (study Group)- Among the 54 subjects, Physical health status (Domain 1) was $72.11 \%$ before intervention, $82.59 \%$ after intervention and $82.59 \%$ follow up. Among the 54 subjects, Psychological health status (Domain 2) was $68.62 \%$ before intervention, $80.22 \%$ after intervention and $80.55 \%$ follow up. Among the 54 subjects, Social Relations status (Domain 3) was $44.22 \%$ before intervention, $44.22 \%$ after intervention and $44.22 \%$ follow up. Among the 54 subjects, Environment factors status (Domain 4) was $73 \%$ before intervention, $79.11 \%$ after intervention and $79.11 \%$ follow up. (Table no. 20).

Table 20: Assessment of quality of life in Group 2 (Study Group)

\begin{tabular}{|l|l|l|l|l|}
\hline & N & Before Intervention & After Intervention & Follow up \\
\hline Physical health (Domian-1) & 54 & 72.11 & 82.59 & 82.59 \\
\hline Psychological health (Domian-2) & 54 & 68.62 & 80.22 & 80.55 \\
\hline Social Relations (Domian-3) & 54 & 44.22 & 44.22 & 44.22 \\
\hline Environment factors (Domian-4) & 54 & 73 & 79.11 & 79.11 \\
\hline Overall & 54 & 64.38 & 71.53 & 71.61 \\
\hline
\end{tabular}

Figure 2: Assessment of quality of life in Group 2 (Study Group)

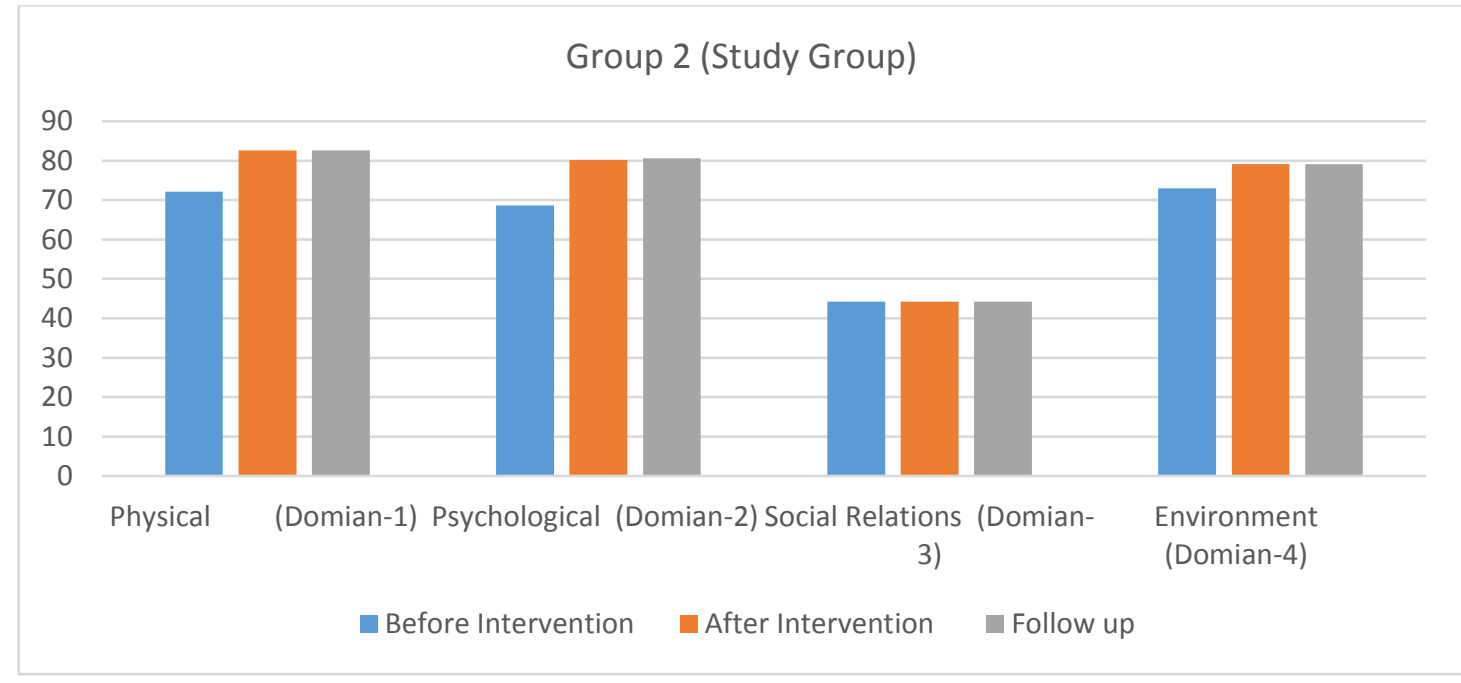




\section{DISCUSSION}

This study aimed to assess the effects of Ashwagandha to evaluate the quality of life of these subjects.

WHO QOL Bref: The quality of life assessment questionnaire of WHO consisted of 26 questions with two subjective questions likely the rating the quality of life and rating the satisfaction of the health. ${ }^{13}$

Effect of Ashwagandha- In Overall results the effect of Ashwagandha improve the quality of life compare to control group. Ashwagandha effects increase in testosterone, which leads to muscle growth and decrease in the level of cortisol, which as catabolic agent detracts from muscle mass. In the term of energy production. Ashwagandha can have beneficial effects on mitochondrial energy level and functioning the reduce activity of the Mg2 dependent ATPase enzyme responsible for the breakdown of ATP and increase creatine levels can in turn leads to ATP generation. Finally, the effect of Ashwagandha on the nervous system as anti-anxiety agent and in promoting focus and concentration may translate to better coordination and recruitment of muscle.

\section{CONCLUSION}

Ashwagandha is one of the rejuvenative and potent supplement to improve the health status. In present study, the subjects had higher scores among the physical, psychological domains compared with the environment and social domains. In comparison with study group and control group the quality of life (WHO BREF) found improved in study group.

\section{REFERENCES}

1. Acharya YT. Charaka Samhita with Ayurveda Deepika commentary of Chakrapani Datta, Reprint edition. Varanasi: Chaukhambha Surabharati Prakashan; 2011.p.62

2. Acharya YT. Charaka Samhita with Ayurveda Deepika commentary of Chakrapani Datta, Reprint edition. Varanasi: Chaukhambha Surabharati Prakashan; 2011.p.62

3. Acharya YT. Charaka Samhita with Ayurveda Deepika commentary of Chakrapani Datta, Reprint edition. Varanasi: Chaukhambha Surabharati Prakashan; 2011p.38
4. K Park, Parks textbook of preventive and Social Medicine, 20th edition, Banarsides Bhanot Publishers, Jabalapur, PP-14.

5. Vagbhata: Astanga Hrdaya, with Sarvangasundara commentary of Arunadatta and Ayurveda Rasayana Commentary of Hemadri, Edited by Pt Hari Sadashiva Sastri Paradakara Bhisagacharya, Edition: Reprint, 2010, Varanasi: Chaukhambha Sanskrit Sansthan, Uttarasthana, PP- 937.

6. Bhavaprakasha Nighantu, commentary by Dr. K.C. Chunekar, Edited by Dr. G. S. Pandey, 9th Edition 1993, Varanasi: Chaukhambha Orientalia, PP-393.

7. Database on Medical plants used in Ayurveda Vol-3 by. P.C. Sharma, CCRAS New Delhi, reprint 2005 PP90.

8. K Park, Parks textbook of preventive and Social Medicine, 20th edition, Banarsides Bhanot Publishers, Jabalapur, PP-13.

9. Database on Medical plants used in Ayurveda Vol-3 by. P.C. Sharma, CCRAS New Delhi, reprint 2005 PP90.

10. Nighantuh: Kaiyadevanighantu, Edited by Prof Priyavrata Sharma, $1^{\text {st }}$ Edition 1979, Varanasi: Chaukhambha Orientalia, PP-193.

11. Sharma GS. Ashwagandharishta - Rastantra Sara Evam Sidhyaprayoga Sangrah - Krishna-Gopal Ayurveda Bhawan (Dharmarth Trust) Nagpur: 1938. pp. 743744.

12. WHO QOL Bref Manual. www. WHO QOL (accessed 5-12-11).

13. WHO QOL Bref Manual. www. WHO QOL (accessed 5-12-11).

\section{Source of Support: Nil Conflict of Interest: None Declared}

How to cite this URL: Bargale Sushant Sukumar et al: A Clinical Study On Effectiveness Of Ashwagandha (Withania Somnifera) On Quality Of Life (Whoqol-Bref) In Apparently Healthy Subjects. International Ayurvedic Medical Journal \{online\} 2020 \{cited December, 2020\} Available from: http://www.iamj.in/posts/images/upload/5268 5278.pdf 